\title{
ステロイドが奏功した踵部潰瘍を伴った無菌性骨髄炎の一例
}

\author{
井戸川 雅 史・高 橋 裕 樹・相 馬 智 彦 \\ 三原 真 美・水越 常 徳・村上 理絵子 \\ 菅谷 寿 晃・牧口 祐介・今井 浩三
}

Jpn. J. Clin. Immun., 23 (3) : 200 208, 2000.

\section{A Case of aseptic osteomyelitis with heel ulcer improved by steroid application}

Masashi Idogawa, Hiroki Takahashi, Tomohiko Soma, Mami Mihara, Tsunenori Mizukoshi, Rieko Murakami, Toshiaki Sugaya, Yusuke Makiguchi and Kohzoh Imai

The first department of internal medicine, Sapporo Medical University

\section{【Summary】}

A 43-year-old male patient was admitted to our hospital because of left heel pain and fever. He had had swelling of the left ankle joint and pain 4 years prior to this, and 4 years later, he was admitted to another hospital when left heel ulcer and fever developed. The ulcer was diagnosed and treated as a diabetic ulcer because of hyperglycemia. In spite of good control of blood sugar, the ulcer became enlarged and the pain deteriorated, so he was transferred to orthopedics. Antibiotics produced no response, and culture from a specimen of the ulcer was negative. However, severe inflammatory response was seen in blood examination. MRI and scintigram of his left foot showed disseminated low intensity areas and accumulation in the tarsal bone area, so osteomyelitis was suspected. A biopsy of the ulcer showed infiltra. tion of inflammatory cells into the dermis. We considered amputation of the left lower leg at first. However the biopsy result suggested an autoimmune mechanism, so prednisolone was administered. As a result, the ulcer and pain both diminished. This case was similar to pyoderma gangenosum, however this diagnosis cannot explain osteomyelitis or all its symptoms. We expect that there must be other case report with the same symptoms.

Key words : skin ulcer, steroid, aseptic osteomyelitis, pyoderma gangrenosum, vasculitis 


\section{【概 要】}

症例は 43 歳男性, 主訴は左踵部痛, 発熱. 平成 5 年上り左足関節腫脹, 自発痛出現. 平成 9 年 1 月発熱と左 踵部潰瘍が出現したため某内科に入院, 高血糖を認め糖尿病性潰瘍として治療を受けた。血糖の改善後も皮膚潰 瘍の拡大と疼痛增強を認め同年 3 月某整形外科に入院. 抗生剤投与も効果なく, 各種細菌培養も陰性であり, 精 查加療のため当院整形外科に転院。著しい炎症反応を認めたが, 潰瘍部の細菌培養は陰性であった. MRIでは 足根骨に T 1 強調で散在する low intensity area, 骨シンチグラムでも足根骨に集積充進を認め骨髄炎が疑われ た. 皮庙潰瘍部の生検では，真皮に炎症細胞浸潤を強く認めた。炎症反応と疼痛の持続から下腿切断が考えられ ていたが，非感染性であり生検所見からも自己免疫機序の関与を疑いプレドニゾロンを投与したところ，潰崵縮 小消失を認めた。本症例は壊疽性膿皮症に近いと考えられたが骨䯣炎の説明は難しく，今後同様の症例蓄積が待 たれる.

\section{I .はじめに}

膠原病および膠原病類緑疾患において，結合組織や 各種臟器に原因不明の慢性炎症が観察される，その炎 症像の多くは非特異的であり, 病理組織学的に診断を 決定するのは困難であるが，免疫担当細胞であるリン パ球・形質細胞主体の細胞浸潤がみられることや，副 腎皮質ステロイド剤が奏功することから，原因として 自己免疫機序が想定される。また特徽的な罹患臟器の パターンや臨床症状・血清学的所見から診断は一般に はさほど困難ではない.しかしながら, 非典型的な経 過を呈する症例や，通常障害されない臓器に原因不明 の炎症が見られた場合，確定診断はしばしば困難であ り, 感染症との鑑別に苦慮することもある.

今回我々は下肢の皮膚潰愓と慢性の無菌性骨髄炎に より下腿の切断術が考慮されたが，ステロイドが奏功 し切断を免れた一例を経験した。診断は確定し得なか ったが，皮膚と骨䯣に病変を有する稀な症例であり， 基盤に自己免疫機序の存在が考えられる各種疾患との 鑑別診断を含めて報告する。

\section{II. 症例}

\section{症 例：43歳, 男性. 事務職.}

主 訴: 左踵部痛, 発熱.

既往歴・家族歴：特記すべきこと無し.

現病歴: 平成 5 年より左足関節嘎脹, 自発痛, 足背 から踵部にかけての皮㢈変色を認めたが，近医にて対 症療法で経過観察されていた. 平成 9 年 1 月, 発熱, 左足の疼痛増悪, 左踵部に潰瘍形成を認め某院内科に 入院. 高血糖を初めて指摘され，糖尿病性皮層潰瘍と の診断にて経口糖尿病治療薬の投与, および創消毒,
抗生㓮投与を受けた。 また, 疼痛に対してはモル七ネ を使用されていた，皮痛病変の改善傾向と血糖値の安 定化を認め同年 2 月退院となったが，直後より潰瘍拡 大，自発痛の増強を認め，同年 3 月某整形外科に入院 した.リポ化プロスタグランジン製剤, 抗生剤を投与 されたが改善がなく, 頻回の細菌培責検查も陰性であ った．発熱も持続するため精查加療の目的で，同年 6 月当院整形外科に入院となった.

入院時現症: 身長 $172 \mathrm{~cm}$, 体重 $42 \mathrm{~kg}$. 体温 $36.0^{\circ} \mathrm{C}$. 脈拍 $68 /$ 分, 整. 血圧 $126 / 90 \mathrm{mmHg}$. 眼瞼 結膜に筫血を認めず，眼球結膜に黄㾝を認めない，胸 腹部に異常所見を認めず. 両側下朖, 足背に暗赤色の 色素沈着を，また左踵部に踵骨の露出を伴う辺縁明 瞭, 径 $3 \mathrm{~cm}$ の潰㿠を認めた（図 1). 左膝関節・足関 節に強い拘縮を認めた。両足背動脈の拍動は良好に触 知された. 神経学的には, 両側足底に軽度の痛覚低下 を認めたのみであった。

入院時検査所見 (表 1): 末梢血では, 軽度の貧血 を認めた。また, CRP $8.11 \mathrm{mg} / \mathrm{d} l$, ESR $132 \mathrm{~mm}$ と 著しい炎症反応の上昇を認めた. HbA $1 \mathrm{c}$ は正常域で あった，尿糖・尿蛋白も認めなかった。 RF は陰性, 血清補体価の低下はなく, 抗核抗体, 抗好中球細胞質 抗体，各種自己抗体も陰性であった，潰瘍部の細菌， 真菌培養は陰性であった。

入院後検查：足部X線写真（図 2) では, 左の足根 骨, 腓骨・脛骨遠位端にびまん性骨透亮像を認めた。 同部の MRI（図 $3 \mathrm{a}$ ）では T 1 強調で同様に散在する low intensity areaを，特に踵骨に強く認めた. Gd による造影効果は認めなかった，皮膚潰湯を伴わない 右足にも，左足よりは軽度ではあるが同様の所見を認 め, 骨髄炎もしくは骨髄腫が考えられた。また, 潰場 

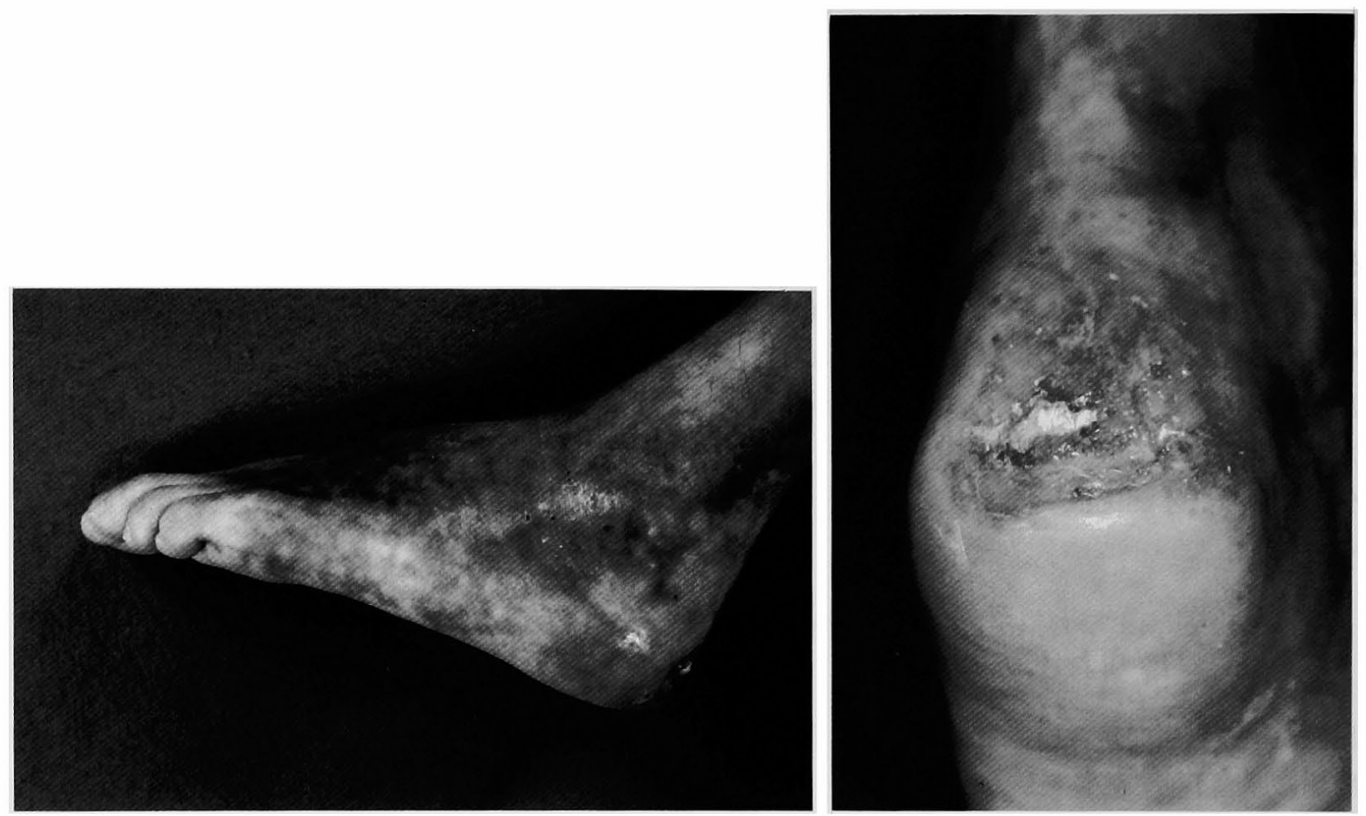

図 1 左踵部皮膚潰場

表 1 入院時検查所見

\begin{tabular}{|c|c|c|c|c|c|}
\hline \multicolumn{2}{|c|}{$<$ Peripheral blood $>$} & \multicolumn{2}{|c|}{$<$ Chemistry $>$} & \multicolumn{2}{|l|}{$<$ Serology $>$} \\
\hline WBC & $6800 / \mu l$ & TP & $7.8 \mathrm{~g} / \mathrm{d} l$ & IgG & $2810 \mathrm{mg} / \mathrm{d} l$ \\
\hline neutro & $64.0 \%$ & Alb & $3.4 \mathrm{~g} / \mathrm{d} l$ & $\operatorname{Ig} \mathrm{A}$ & $500 \mathrm{mg} / \mathrm{d} l$ \\
\hline lymph & $31.0 \%$ & $\alpha 1$-glob & $6 \%$ & IgM & $123 \mathrm{mg} / \mathrm{d} l$ \\
\hline mono & $3.0 \%$ & $\alpha 2$-glob & $10.8 \%$ & & \\
\hline eosino & $2.0 \%$ & $\beta$-glob & $8.8 \%$ & & \\
\hline $\mathrm{RBC}$ & $\underline{343 \times 10^{4} / \mu l}$ & $\gamma$-glob & $\underline{31.3 \%}$ & & \\
\hline $\mathrm{Hb}$ & $8.1 \mathrm{~g} / \mathrm{d} l$ & T-Bil & $0.2 \mathrm{mg} / \mathrm{d} l$ & C 3 & $124 \mathrm{mg} / \mathrm{d} l$ \\
\hline $\mathrm{Ht}$ & $26.7 \%$ & D-Bil & $0.0 \mathrm{mg} / \mathrm{d} l$ & $\mathrm{C}_{4}$ & $27 \mathrm{mg} / \mathrm{d} l$ \\
\hline $\mathrm{MCV}$ & 77.8 & AST & $13 \mathrm{IU} / l$ & $\mathrm{CH} 50$ & $49.2 \mathrm{U} / \mathrm{m} l$ \\
\hline $\mathrm{MCH}$ & 23.6 & ALT & $21 \mathrm{IU} / l$ & $\mathrm{RF}$ & $(-)$ \\
\hline $\mathrm{MCHC}$ & 30.3 & $\mathrm{LDH}$ & $167 \mathrm{IU} / l$ & ANA & $(-)$ \\
\hline Plt & $55.8 \times 10^{4} / \mu l$ & ALP & $371 \mathrm{IU} / l$ & $\mathrm{P}-\mathrm{ANCA}$ & $(-)$ \\
\hline Reticul & $8 \%$ & $\begin{array}{l}\text { ChE } \\
\gamma \text {-GTP }\end{array}$ & $\begin{array}{l}203 \mathrm{IU} / l \\
66 \mathrm{IU} / l\end{array}$ & $\beta 2$-GPI Ab & $(-)$ \\
\hline \multicolumn{2}{|c|}{$<$ Coagulation $>$} & BUN & $9 \mathrm{mg} / \mathrm{d} l$ & FBS & $91 \mathrm{mg} / \mathrm{d} l$ \\
\hline $\mathrm{PT}$ & $58.7 \%$ & UA & $5.7 \mathrm{mg} / \mathrm{d} l$ & $\mathrm{CRP}$ & $8.11 \mathrm{mg} / \mathrm{d} l$ \\
\hline \multirow[t]{2}{*}{ APTT } & $48.1 \mathrm{sec}$ & $\mathrm{Cr}$ & $0.5 \mathrm{mg} / \mathrm{d} l$ & anti-HTLV Ab & $(-)$ \\
\hline & & $\mathrm{Na}$ & $135 \mathrm{mEq} / l$ & anti-HIV $\mathrm{Ab}$ & $(-)$ \\
\hline \multirow{6}{*}{ ESR } & $132 \mathrm{~mm} / \mathrm{hr}$ & $\mathrm{K}$ & $4.5 \mathrm{mEq} / l$ & & \\
\hline & & $\mathrm{Cl}$ & $99 \mathrm{mEq} / l$ & PPD & $(-)$ \\
\hline & & $\mathrm{Ca}$ & $8.7 \mathrm{mg} / \mathrm{d} l$ & & \\
\hline & & $\mathrm{P}$ & $3.9 \mathrm{mg} / \mathrm{d} l$ & $<$ Urinalysis $>$ & \\
\hline & & T-Chol & $73 \mathrm{mg} / \mathrm{d} l$ & protein & $(-)$ \\
\hline & & TG & $41 \mathrm{mg} / \mathrm{d} l$ & sugar & $(-)$ \\
\hline
\end{tabular}




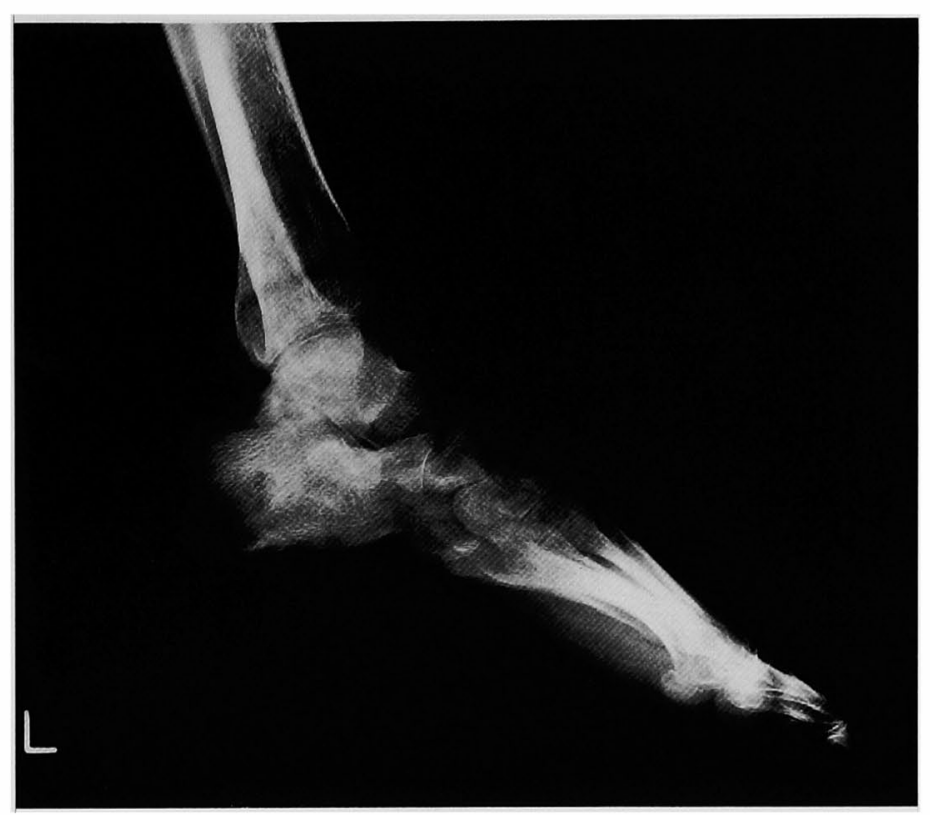

図 2 左足部 $X$ 線写真

部を含めた皮膚軟部組織と踵骨内の low intensity areaには連続性を認めなかった。骨シンチグラム （図 4）では，血流相では，左足の血流増加によるイ メージ増加を, 血液プール相で左踵骨を中心に脛骨遠 位端, 距骨, 足根骨に集積六進を認めた。骨相でも同 様に集積を認め, MRI 所見とあわせて骨髄炎が最も 疑われた，右足には異常集積を認めなかった。皮膚潰 瘍部の生検（図 $5 \mathrm{a}$, 潰瘍形成 4 力月後）では, 真皮 主体に形質細胞・リンパ球を主体とする細胞浸潤を認 めたが, 好中球浸潤は軽度であった。また, へモジデ リンを食食したマクロファージが多数認められること から, 経過中の何らかの血管侵襲が考えられた. 血管 や付属器周囲にも細胞浸潤を認めたが, 明らかな壊死 性血管炎の像は認められなかった. 皮下脂肪織への炎 症細胞浸潤は軽度であった。 また, 左脛骨遠位端の生 検（図 5 b) では骨髄は細胞成分に乏しくびまん性の 線維化を認め, 陳旧化した骨髄炎の所見であった. 胸 腹部 CTでは異常を認めなかった.

入院後経過（図 6)：難治性の皮膚潰锡と原因不明 の両下肢骨䯣炎の遷延がみられたが, 血糖コントロー ルは良好で糖尿病性壊瘨は否定的であった。 また抗生 剤の投与は効果なく, 各種細菌培養も陰性で感染性の 皮膚, 骨髄病変も考えにくいと思われた. 経過中, 関 節痛, 筋痛は認められなかった. CRP $7 \mathrm{mg} / \mathrm{d} l$ 以上 と炎症反応高値が持続し, また疼痛のため一月以上の
モルヒネ継続服用（硫酸モルヒネ徐放剤内服 $30 \mathrm{mg} /$ day）を要する状態であることから，外科的な治療方 針として, 左下腿の切断が考えられていた。一方，皮 膚生検組織像では確定診断は得られなかったが, 強い 炎症細胞浸潤と血管侵襲の存在が示唆されたこと, お よび原因不明の慢性炎症が持続している臨床経過と併 せて, 血管炎症候群あるいは Weber-Christian 病な どの自己免疫疾患の関与が疑われたため, 平成 9 年 7 月に当科に転科となり，患者本人の了承を得てプレド ニゾロン（以下 PSL） $40 \mathrm{mg}$ の投与を開始した. PSL 内服開始直後より, CRP の著しい減少, 発熱 疼痛の消失をみとめ, 潰瘍の縮小, 肉芽の形成がみら れた。モモヒネも漸減され，9月に中止された。体重 は 9 月より増加し 12 月には $49 \mathrm{~kg}$ となった. 同年 12

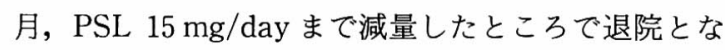
った. PSL 内服開始 3 力月後に撮影された, 左足 $\mathrm{T} 1$ 強調 MRI 像（図 3 b）を示す. 足根骨に散在した low intensity area の縮小, 消失を認めた。その後, 平成 11 年 8 月時点で PSL $15 \mathrm{mg}$ を服用中であるが炎 症反応は認められず，潰瘍は治癒し歩行可能な状態で ある。

\section{III. 考 察}

本症例は皮膚潰湯に骨髄炎を伴っており，いずれの 病変に対してもステロイド剤が有効であったと考えら 


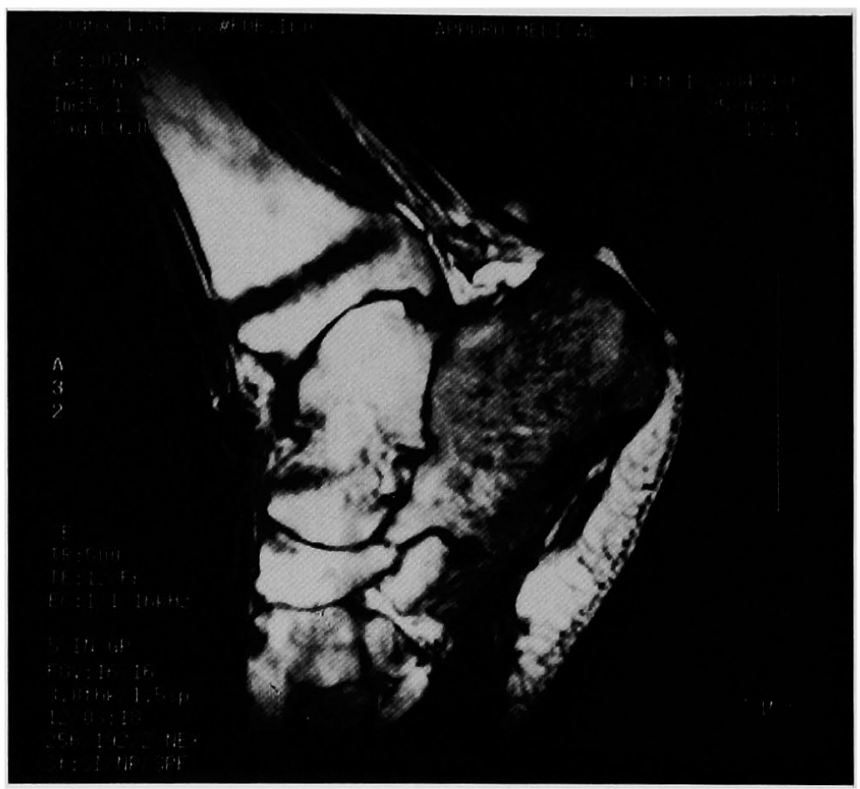

a ）入院時

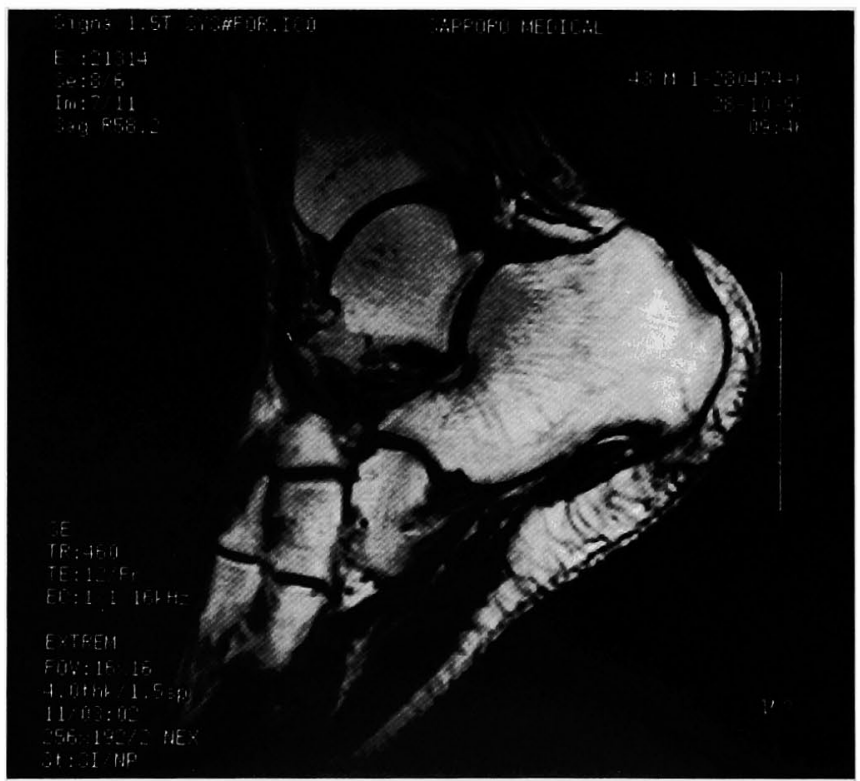

b ) PSL 内服後 3 力月

図 3 左足部 MRI（ $T_{1}$ 強調 $)$

れた，血糖コントロールは良好で糖尿病性壊疽は考え にくく,また抗生剤の投与は効果なく各種細菌培養も 陰性であったことから感染症も否定的であった，画像 的に皮膚潰瘍と骨髄病変の間に連続性がなく，また右 足部骨髄にも病変が認められることから，皮膚潰場は 単なる骨髄炎の直接進展による病変ではなく，共通の
病因により皮膚と骨髄に炎症が出現したものと考えら れた，皮膚と骨髄病変を呈し，ステロイドが有効であ る疾患としてはWeber-Christian 病, Sweet 病, SAPHO 症候群, 血管炎症候群, 壊疽性膿皮症が挙げ られる. Weber-Christian 病では, 数 $\mathrm{mm}$ から 20 $\mathrm{cm}$ 大の比較的境界明瞭な皮下結節を生じ, 時に潰瘍 


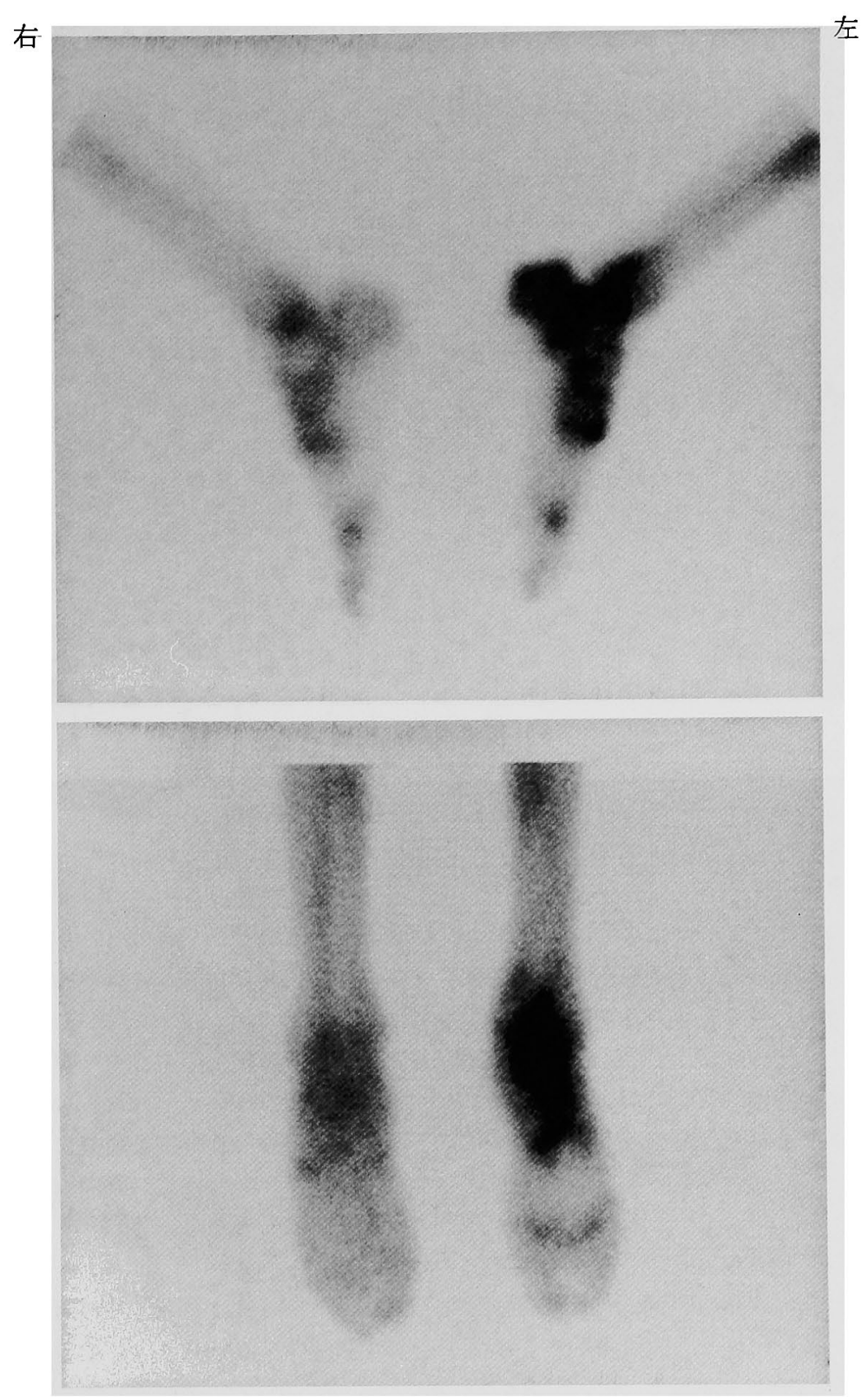

図 4 足部骨シンチグラム

を形成するが，本疾患に特徵的とされる脂肪織炎が本 例では皮膚・骨䯣ともに認められず否定的であった。 Sweet 病では，典型疹と呼ばれる有痛性隆起性紅斑 が認められる，浮腫性で, 病理学的には真皮への好中 球を主体とする細胞浸潤が特徴的であり，多数の好中 球浸潤による膿疮形成から潰瘍となることもある.し かし本症例では好中球浸潤は殆どないため典型疹によ る潰瘍とは考えられず，またSweet 病に骨髄炎を通
常合併しない事から Sweet 病は否定的であった. 掌 蹠膿疮症や痤瘡に骨堌殖, 骨髄炎, 滑膜炎を伴う疾患 として SAPHO 症候群がある. 本症例では皮覤所見 は踵部潰瘍のみであり, 骨増殖や滑膜炎は認めなかっ た。また骨病変として, 骨生検で Paget 病様の骨過 形成, 炎症細胞浸潤を認め, しばしば化骨細胞と破骨 細胞を多数伴うが, 本症例の骨生検ではこれらの所見 も認められず SAPHO 症候群も否定的であった. 発 


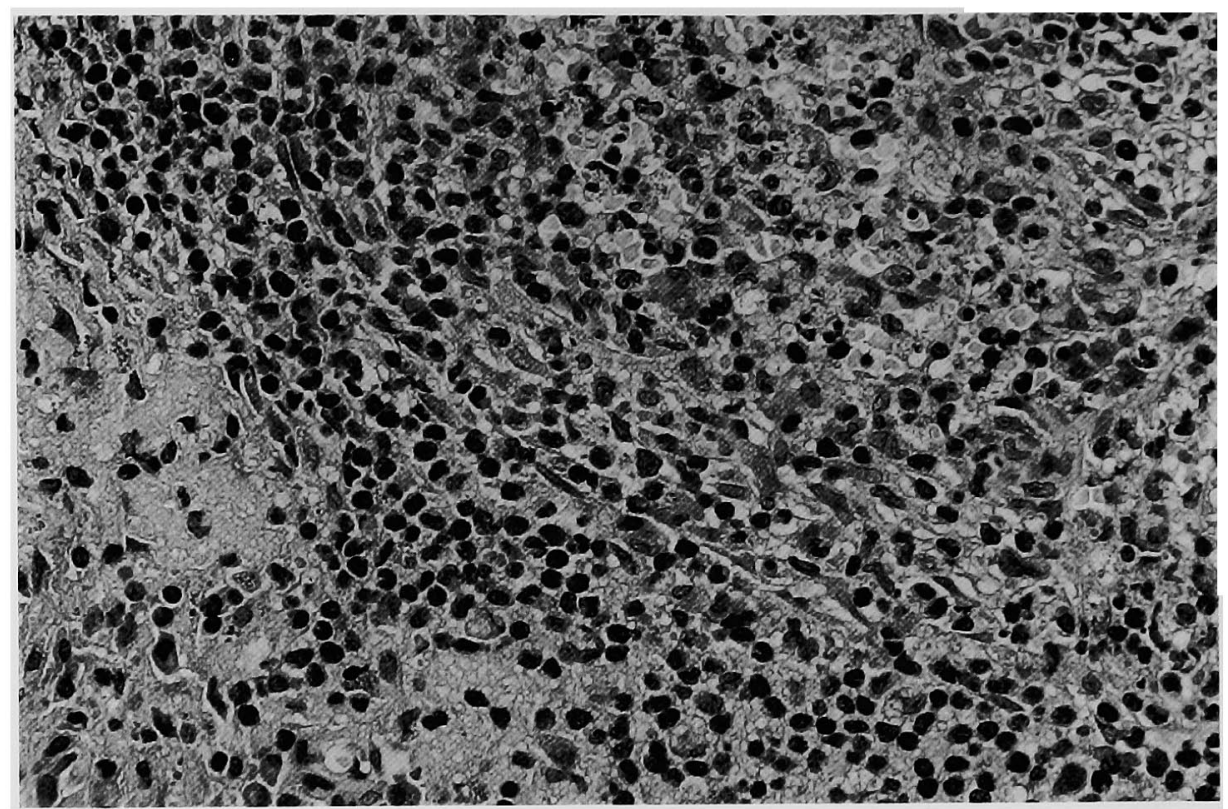

a ）潰瘍周辺部皮䖉

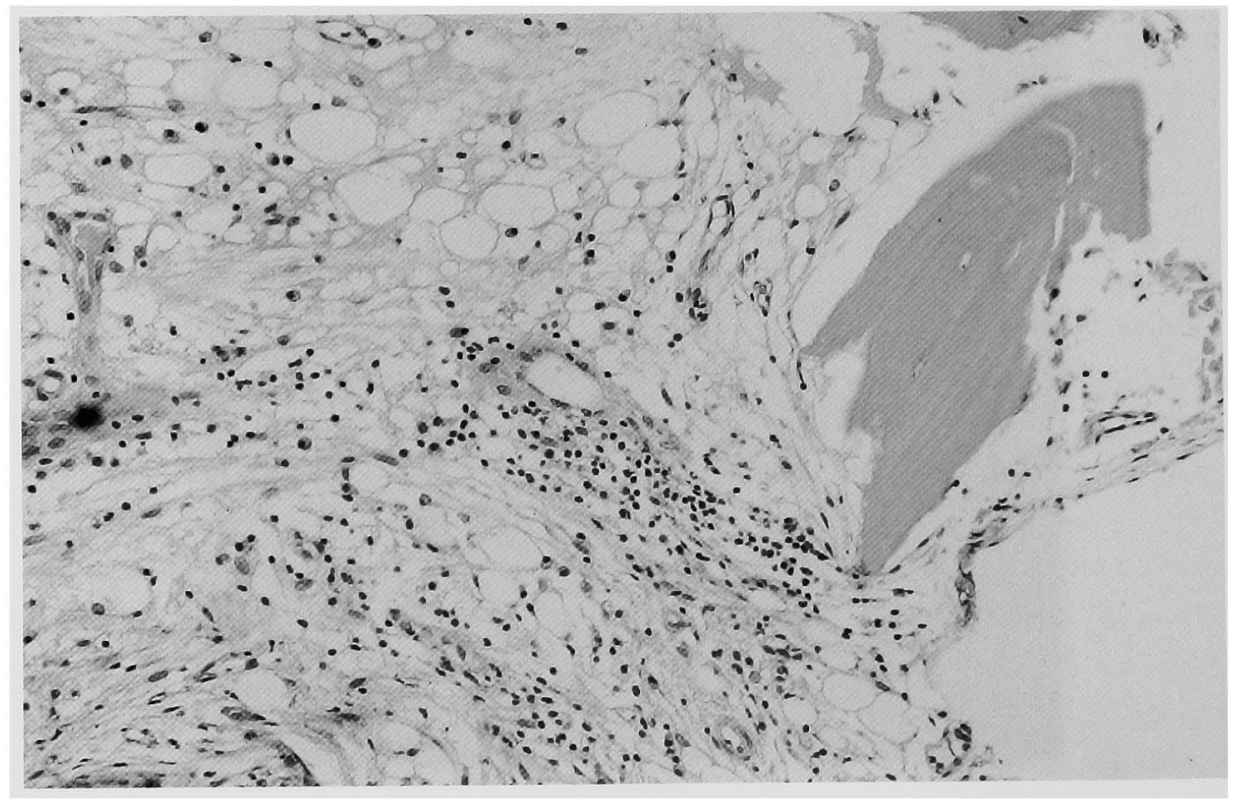

b）左脛骨遠位端

図 5 生検組織像

熱や体重減少，皮膚潰場の存在は結節性多発性動脈炎 を強く疑うが，皮鬳組織像からは血管炎の確定診断に は至らず，また多彩な病変を示す血管炎の中でも骨䯣 病変は報告がなく，本例の皮膚・骨髄病変を血管炎に 上り一元的に説明するのは困難であると考えられた。
壊疽性膿皮症は, 明瞭で紫紅色の境界を持つ潰瘍を形 成し，上皮の壊死に伴う炎症の真皮への波及から縁下 穿掘性を示す。病変は, 単発または多発性で周囲に炎 症性紅斑を伴う境界明膫な膿疮から生じ，融合するこ とにより潰湯を形成する，症状として発熱，全身倦意 


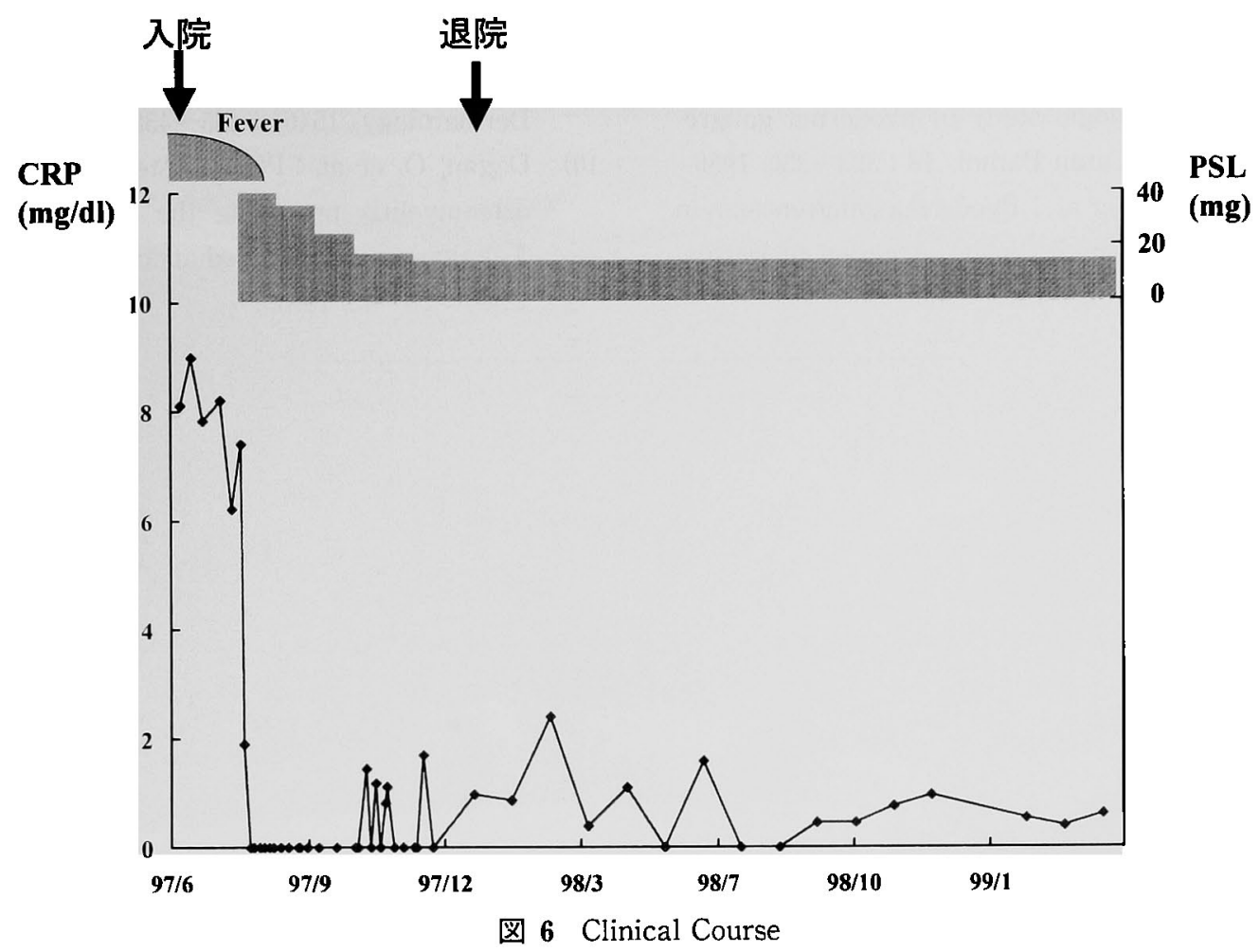

感, 筋痛, 関節痛を伴うことがあり, 特に下腿に好発 するとされる，病理学的特徴としては特異的なものは 少なく, 多数の好中球浸潤と出血, 上皮壊死を認め る.また，まれに骨融解・骨髄炎の合併が報告されて いる 5,6,8 10). 本症例では, 発熱, 全身倦意感を認め, 潰愓の肉眼所見もこれに類似していた。組織の好中球 浸潤は軽度であったが, 病期によりリンパ球浸潤を認 めるという報告もあり7，必ずしも矛盾しないと思わ れた。

本症例は，上記の鑑別診断に照らし合わせた場合， 壊㾇性膿皮症に最も近いと考えられたが，無菌性骨䯣
炎について十分に説明することは難しく，ステロイド が著効したことから, 何らかの自己免疫機序の関与し た病態が示唆された。また，末梢循環障害が病像を修 飾している可能性も考えられた. 今後同様の病像を呈 する症例の蓄積により, 病態が解明されること,およ び適切な治療法が確立されることが待たれるところで ある。

謝辞：貴重な資料・情報を提供していただいた国立 療養所札幌南病院の山崎修司先生, 藤田正樹先生にこ の場を借りて深謝申しあげます。
1)溝口昌子：Sweet 病. 日本臨床免疫学会会 誌, $19(3): 169 \sim 178,1996$.

2) Boutin, R.D., et al. : The SAPHO Syndrome. American Journal of Rhumatology, 170 (3) : 585 591, 1998.

3) Callen, J.P. : Pyoderma gangrenosum. Lancet, $351: 581 \sim 585,1998$.

4) Prystowsky, J.H. et al. : Present Status of
Pyoderma Gangrenosum. Arch Dermatol, 125(1) : 57 64, 1989.

5) Samlaska, C.P. et al. : Pyoderma gangrenosum and cranial osteolysis. British Journal of Dermatology. 133: 972 977, 1995.

6) Signs, D.J. et al. : Pyoderma Gangrenosum Complicated by Underlying Osteomyelitis. Clinical Infectious Disease, $21: 1523 \sim 1524$, 
1995.

7) Su, W.P.D. et al. : Histopathologic and im munopathologic study of pyoderma gangrenosum. J. Cutan Pathol, $13: 323 \sim 330,1986$.

8) Schaen, L., er al. : Pyoderma gangrenosum in association with CRMO. Archives of Dermatology, 134 (9) : 1149 1150, 1998.
9) Omidi, C.J., et al. : CRMO preceding PG and occult UC in a pediatric patient. Pediatric Dermatology, 15(6) : 435 438, 1998.

10) Dagan, O. et al. : PG and sterile multifocal osteomyelitis preceding the appearance of Takayasu arteritis. Pediatric Dermatology. 12(1) : 29 42, 1995. 